\title{
綜 説 \\ 病巣感染について
}

佐藤 重 -

緒

言

病巣感染についての研究の歴史は既に半世紀前より始まるもので，カナダのハンター，アメリカ のビリングス等によつて特に唱道された。なかんずく，アメリカに於てはこれが甚だしく過大視せ られ, 病巣の 1 つなる扁桃剔出が無批判的に行わるるに至つた。然し其後, 反省是正せられたのみ ならず，反動的に成つた程である。ドイツに於てもアメリカと相前後してこの問題が取扱われたが， その最初の研究者はペスラーであつた。ドイッに於ては終始これが泠静に取扱われていたが，此問 題は既に 2 回も宿題報告となり，20年前にグットッアイト等によつて綜合的に緾められてその性格 が明かになつた。

吾国においては，今上り20数年前より此問題は注意せらるるようになつたが，始めは主として内 科方面に於てとり上げられ，殊に昭和17年に千葉医大の堂野前教授がこれに関心をもたれて系統的 に研究せられしに及んで，此問題は吾国に於ても爼上に上つてきた感がする。取鼻咽啝科方面にお いては, 九大の算木教授が昭和15年, 学会総会に於て, 扁桃問題に就て宿題報告老行われし際, 此 問題にも触れたが，その後九大教室よりこれに関する研究発表が展乃行われている。

また数年前より東京国立第 2 病院の猪博士およびその指導下にある人々の研究発表を見，殊に昭 和34年において, 日本耳鼻咽唉科会々報誌上に木村氏の発表がある。さらに同年耳鼻咽喉科臨床誌 上に京都大学耳鼻科教窒の溝上氏のこれ関する研究発表を見ている。

吾国にお打る此問題の研究は余り高低の激しい波を見せておらぬが，終始此問題には関心が払わ れて㧍り, 今35年春の内科学会の宿題報告として, 堂野前教授から述べう，文耳鼻科に於ては明 年度の宿題報告として熊本大学の野坂教授より発表せらるる予定であり；最近殊に関心が昂つたよ うに思惟せらるるので，この機会に其概要について述べたいと思う。

なお外国においても最近の $2 ， 3$ 年来本症に関する記載が比較的に増加しており，殊にイタリヤ における交献が多いようである。

定

病巣感染とはグットツアイトの云う如く「どこかに 慢性的の感染性・炎症性の病巣があつて，そこにおい ては特別に顕著な病的病状を呈さないが，それが原因 となつて遠隔なる身体の個所において，2次的の著明 なる病的現象を起すこてがある。これを病巣感染とい う・」、以上のうに定義されているのが適当と思う。 し袈してその原病巣と認められるものは, 扁桃, 歯 牙, 副鼻腔为その主なるもので, 従つてわが耳鼻咽喉

\section{義}

科とは甚だ密接な関係にある。

その他, 虫垂, 䏣垔, 泌尿器官, 子宮附属器, リン パ腺, 前立腺も原病巣となり得る.

またこれより起る 2 次的疾患は，実に多種多様でモ ーレの表示するところによれば，その数53種を数える ことが出来るが，その主なるものは，腎炎，心臓疾 患, 多発性関節炎, 結節性紅斑, エリテマトージス, ある種の眼疾患, 神経痛微熱等が挙げられている。

* 東京沙患会医科大学名誉教授 


\section{腎 炎との 関 係}

殊に最近割合活発に論ぜられているのは，扁桃と腎 炎との関係である。殊に小児の腎炎の場合には，その 半数が習慣性アンギーナに䍜患したという病、歷があ り，アンギーナと腎炎との間に深い関係のあることが 考元られる，腎炎の場合に，扁桃を剔出すべきや否か の問題は，常にわれわれ耳鼻科医に課せらるる命題で あるが，かかる場合，2つの場合が考えられる，その 1 つの場合は腎炎の治療が行なわれているに拘らず， 何時まで経つても蛋白が消失せぬため，原病巣と，思惟 :せらるる扁桃を剔出せばあるいは治㾍を期待し得るの ではないかと云う希望をもつて意見を徴せらるる場合 と，なほ 1 つには，一度腎炎が全快せしにも拘らず， アンギーナを惹起する機会に，容易に尿に蛋白の析出 するが故に，その予防のために扁桃を剔出することを 希望してくる場合とがある。

この後者の場合には簡単に解決し得るが，前者の場 合には時に考慮の要せらるる場合がある。事実，病巣 感染源たる扁桃を剔出してより，篃炎による蛋白尿の 消失したという事実は屢々われわれの耳にするところ である.

扁剔によつて腎炎の治瘾せりという頻度が，実施例
の50乃至 $80 \%$ という報告に接する，然し常にかかる成 績が得らるるや否かは再検討の要があると思う。われ われは最近，腎炎患者において，内科的治療を長く続 けたにも拘らず，蛋白尿がなかなか消失世故の理由 の下に，扁剔を実施せし幾つかの症例を有している。

その結果を表 1 の如く表示するに，効果の認められ し場合も2，3 の症例において認め得るが，概してよい 成績とは云うことが出来ない。

その理由はわれわれの症例の大多数は; 罹患後皆 1 カ月以上を経過せるものにて，なかには年余を経過し ているものもある。すなわち，腎炎の新鮮なる症例を 取扱わなかつたというところにその原因があつたか，と 思う。

九州福岡方面においては，腎炎発病後10２0日間の 間において扁剔を行なえば，常に良好なる結果が得ら れるとなし，早期手術を提唱せる向きもある。しかし 余り早期においてすると，急性腎炎の症状の一時悪化 する傾向も考えられる，文献に徴するに，加るる腎焱 の一時的堌悪が扁剔実施例 23 例中に，20例の多数にお いて見られたという報告もあるので，その実施の時期 について細心の注意を要する。

表 1 腎炎症例 (20例)

\begin{tabular}{|c|c|c|c|c|c|c|c|c|}
\hline 症 例 & 姓 名 & 年令 & 性别 & (発病 $\rightarrow$ 扁剔) & （扁剔 $\rightarrow$ 検査日） & (蛋) & $\begin{array}{l}\text { 扁 } \\
\text { 前 }\end{array}$ & 剔 \\
\hline 1 & & 25 & 吕 & $3 \mathrm{~W}$ & $50 \mathrm{~T}$ & & \pm & \pm \\
\hline 2 & & 18 & 占 & $1 \mathrm{M}$ & $2 \mathrm{~J} 5 \mathrm{M}$ & & H & m \\
\hline 3 & & 21 & 우 & $1 \mathrm{M}$ & $2 \mathrm{~J}$ & & + & \pm \\
\hline 4 & & 26 & 古 & $3 \mathrm{M}$ & $12 \mathrm{M}$ & & H & H \\
\hline 5 & & 16 & 古 & $3 \mathrm{M}$ & $4 \mathrm{M}$ & & \pm & + \\
\hline 6 & & 19 & 우 & $3 \mathrm{M}$ & $11 \mathrm{M}$ & & + & \pm \\
\hline 7 & & 20 & ઠ & $4 \mathrm{M}$ & $5 \mathrm{M}$ & & $H$ & + \\
\hline 8 & & 33 & 今 & $5 \mathrm{M}$ & $7 \mathrm{M}$ & & + & + \\
\hline 9 & & 48 & 古 & $7 \mathrm{M}$ & $1 \mathrm{~J} 3 \mathrm{M}$ & & \pm & \pm \\
\hline 10 & & 17 & 古 & $9 \mathrm{M}$ & $1 \mathrm{~J} 4 \mathrm{M}$ & & W & H \\
\hline 11 & & 20 & 古 & $1 \mathrm{~J} 6 \mathrm{M}$ & $1 \mathrm{~J} 6 \mathrm{M}$ & & - 冊 & \# \\
\hline 12 & & 23 & 우 & $8 \mathrm{~J}$ & $2 \mathrm{M}$ & & W & H \\
\hline 13 & & 20 & 우 & $12 \mathrm{M}$ & $3 \mathrm{M}$ & & 世 & \# \\
\hline 14 & & 9 & 今 & $5 \mathrm{M}$ & $10 \mathrm{M}$ & & + & \pm \\
\hline 15 & & 21 & 우 & $3 \mathrm{~J} 9 \mathrm{M}$ & $6 \mathrm{M}$ & & $H$ & + \\
\hline 16 & & 27 & 占 & $4 \mathrm{M}$ & $6 \mathrm{M}$ & & + & + \\
\hline 17 & & 16 & 古 & $2 \mathrm{M}$ & $2 \mathrm{M}$ & & + & + \\
\hline 18 & & 19 & 우 & $40 \mathrm{~T}$ & $3 \mathrm{~T}$ & & + & - \\
\hline 19 & & 28 & 占 & $1 \mathrm{~J} 4 \mathrm{M}$ & $4 \mathrm{M}$ & & + & - \\
\hline 20 & & 30 & 古 & $2 \mathrm{M}$ & $1 \mathrm{M}$ & & + & \pm \\
\hline
\end{tabular}




\section{余が経験せし病巣感染の 2,3 の症例}

病巣感染についての臨床例は日常の診療の際，多く の人の経験せらるるところであるが，余は茲に記憶に 存する2,3の症例に就いて述へててなた。

1. しばしばアンギーナに䍜り仕事上障害になつて 困ると訴うる 1 代議士. 扁剔施行後, 心曆六進は治 し，階段を昇る時，息が切れなくなつた。因みに本症 例は術前の心電図においても変化があつた。なほ不正 脈も術後消失した。

2. 扁桃周囲膿瘍の患者において，切開・排膿を講 じ局所は軽快したが，引続いて小舞踏病の発作を起し た。

3. アンギーナを起す毎に，口内炎を併発する習慣 を有する患者において，炎症の間歇時に扁剔を行ない しところ，これが動機となり上下の口唇に甚だしきへ

発生 病巣感染の発生機序については，色々の説がある がそその主なるものの1つに細菌説がある。すなわ ち, 細菌あるいはその毒素が扁桃の深部に存して，こ れが血流またはリンパ流を介して身体の遠隔の籄処に 摙ばれ，そこに二次的疾患を起すという説である。

その際溶レン菌が主なるものなることは既に知らる るところである.

次に病巣感染は抗元抗体反応の結果によるという説 である.これは主として菌毒素または組織崩壊物質が 組織内に侵入し，これが抗元となりこれに対する抗体 が生じ，この抗元抗体反応の起る際にこれを楔機とし て二次的疾患が起るという説で，これはアレルギーと 同様に理解され，従つて病巣感染は一種のアレルギー 性変化であるという説である.

堂野前教授の病巣感染の成立に関する学説は, アレ ルギー機序がその主役を演ずると云うのである，その 際の抗元としては，従来考えられていた細菌およびそ れに由来する物質の外に，宿主と細菌との交渉によつ て生じた病巣産物すなわち，自家抗元が最も重要なる 意義を有するとなし，これを氏は病巣抗元と名付け た.しかしてこの主体は病巣産物中の蛋白質特にその オイグロブリッ分画にあることを確認した。

なお慢性扁桃炎の如き限局性炎病巣を有する患者の 血清中に病巣抗元に対する抗体の存在を証明したと云

診

これは主要なる部分である。診断法に関しては表 2
ルペスを生じた。

4. 脑部所見の全く陰性になりし結核患者におい て，微熱のみが如何にしても去らぬ者が，偶々アンギ 一ナを起し高熱を発し，これに処置を講じ，アンギー ナの終熄せしことを楔機として従来の微熱が消失し た。

5. ラジオドラマの声優. 始終音声を害して職務遂 行に支障を来たし困却せるもの，慢性屚桃炎を有せし ため，扁剔を行ないしに，術後全く喉頭病変去りて仕 事に困らなくなつた。これはアレルギー性変化が近接 器官においても発し得るという所説をよく物語るもの と思う。

以上は単に余が経験せし臨床例の一部を断片的に述 ベたに過ぎない.

\section{機序}

われている。

現在においては，このアレルギー機序によるという 説が最も支配的であるようである.

次には慶大鈴木助教授等の提唱するレーリー現象に よるという説である.同教授は Focalinfection と云 はず Focaused-Reaktion と云うべきであると述べて いる，氏等の説によれば，過剩剌㦸为自律神経を介し て色々の臓器, 就中末梢毛細血管系に影響をおよほす ものであると主張している，例えば，皮膚に与えられ た過剰剌㦸により，扁桃炎の如き自律神経に富む部位 に焦点反応が起り，しかして血管系の変化が起り，こ れによりバイ菌の活動が盛んになり，扁桃炎が併発さ れるのであるという.しかしてこの剌㦸は色々の器官 殊に心，腎等に伝達される.しかして始めは Reaktion という程度に止まるが，この時既に心電図上に変化を 現わすがこれはまだ病理組織学的の变化でないた め，扁剔等の処置によつて容易に恢復するものであ る. しかし過剩刺㦸が繰返し加へられると, 䓋に始め て器質的の変化を招来するものであるという.

なお病巣感染の機序に就て， disproteinamische Reaktion 説がある.これは身体の何処かに蛋白崩壊 を来す病巣があつて，それが長く存すると血中蛋白の 異常変動を来たし，心，腎等に退行変性を起すもので あるという説である。

\section{断}

に示す如くである。 
表 2 主なる診断法
1. 病歴と一般状態
2. 局所々見
3. 誘 発 法
1）マッサージ
2）超短波照射
4. A S R
5. 心 電目
6. 血漿蛋白分屑
7. 扁桃洗涂法
8. 扁桃穿刺物皮内反応
9. Impletol 反応
10. Remky 及び Weltman 反汒

第 1 の診断法たる病歴と一般症状に就てであるが， 病歴に関しては特に習慣性アンギーナを有するや否や に就て検討すべきである.

本症患者は往々にして，平生より全身倦㤐感，肩凝 り等の自覚症を有する。また微熱を有することもあ る。咽頭部においては，咽頭の異和感を訴えることも ある。

血液検査に当りては，白血球殊にリンパ球の増加を 認め, また血沈の促進を認める.

第 2 は局所々見であるが，扁桃を観察すると，扁桃 に必ずしも腫大あるとは限らない。埋没性であること が普通である。その表面は凹凸を呈し，腺窩殊に上扁 桃窩の窩入口部は開大していて，腺窩内にはプロツプ が存し，また扁桃を圧してみると分泌物の出づること がある．要するに慢性扁桃炎の所見を呈する.

若しかかる扁桃を剔出する場合には，剝離に際して 瘜着を認めることが普通である。しかして扁桃を除去 した後にはその基底にしばしば膿汁の存するを認め る。また䪽下リンパ腺も腫脹していることがある。

第 3 は誘発法である。病栄感染源となつている扁桃 を剔出して，それによつて二次的現象を起している個
所の影響を観察することによつて始めて的確な診断を 下し得るのである。 (Diagnosis ex juvånntivus) 然 しかかる方法では，時に無益の手術を施行する場合も 起るので，手術前に予め診断を確定する必要がある. これに対する診断法の一つに誘発法がある。誘発法に も2. 3 の種類があるが，マッサーヂ法もその一つであ る.これは扁桃に 5 分間マッサーギを行なうのであ る. 然し本法よりも実施し易い方法として，超短波照 射がある。これは頸部より扁桃に向つて左右各々 5 分 間宛照射して一定時間後に白血球の算定, 血沈の測定 を行なつて，これを実施前におけるものと比較してそ の増減を検するのである。然し照射後待㙨する時間は 45分位でよいという説もある。しかしてかがる照射に よつて白血球が 2 千以上に增加を示し，血沈が10より 以上の上昇を来たす場合をもつて陽性成績となす。ま た陽性反応として照射後微熱を発することや，頭痛， 全身僚吝感を訴えることもある。

第4の診断法として Antistreptolysin Reaktionが ある.これは扁桃炎の場合においては菌は殆んど溶レ ン菌であることより，その菌に対する抗体価を測定す ることである，普通健康人の抗体価は150単位とされ ているが, 病栄感染を起せる場合には, これが 200単 位以上となる。この時には菌感染を起せるものと解釈 される.

またこの時には沈降反応も陽性になつている場合が 多いのであつて，この両者は常に平行性をもつている 場合が多い．われわれも少数例に就てではあるが，こ のA.S.R 法を実施してみた。すなわち，“病巣感染を 起せると認められる症例およびこれと対照的に急性扁 桃炎，単なる慢性扁桃炎等の症例に本反応を応用して みて, 表 3 に見らるる如き結果を得だが，概して病栄 感染群において抗体価は高く, 急性扁桃炎の如き場合 において概して低く，単なる慢性徧桃炎の如き場合に

表 3 A S L （抗体 価）Todd単位

\begin{tabular}{|c|c|c|c|c|c|c|c|c|c|}
\hline \\
\hline \multicolumn{3}{|c|}{$\underbrace{}_{\text {病 }}$ 症体侕 } & \multirow{2}{*}{$\frac{100}{1}$} & $\frac{125}{3}$ & \multirow{2}{*}{$\begin{array}{l}250 \\
2 \\
1 \\
1\end{array}$} & \multirow{2}{*}{500} & \multirow{2}{*}{$\begin{array}{c}833 \\
1 \\
1 \\
1\end{array}$} & \multirow{2}{*}{$\begin{array}{r}1250 \\
1 \\
1\end{array}$} & \multirow{2}{*}{2500} \\
\hline $\begin{array}{l}\text { 扁 } \\
\text { 桃 } \\
\text { 病 } \\
\text { 篾 } \\
\text { 染 } \\
\end{array}$ & $\begin{array}{l}\text { 腎 } \\
\text { 口 } 1 \text { 炎 } \\
\text { 心 内 膜 炎 } \\
\text { ロイマ性紫班病 }\end{array}$ & $\begin{array}{l}7 \\
2 \\
3 \\
1\end{array}$ & & 3 & & & & & \\
\hline 対 & 急性扁桃炎 & 13 & 3 & 3 & & & 1 & & \\
\hline 称 & 慢性, 扁桃炎 & 26 & 2 & 9 & 7 & 3 & 3 & 1 & 1 \\
\hline
\end{tabular}




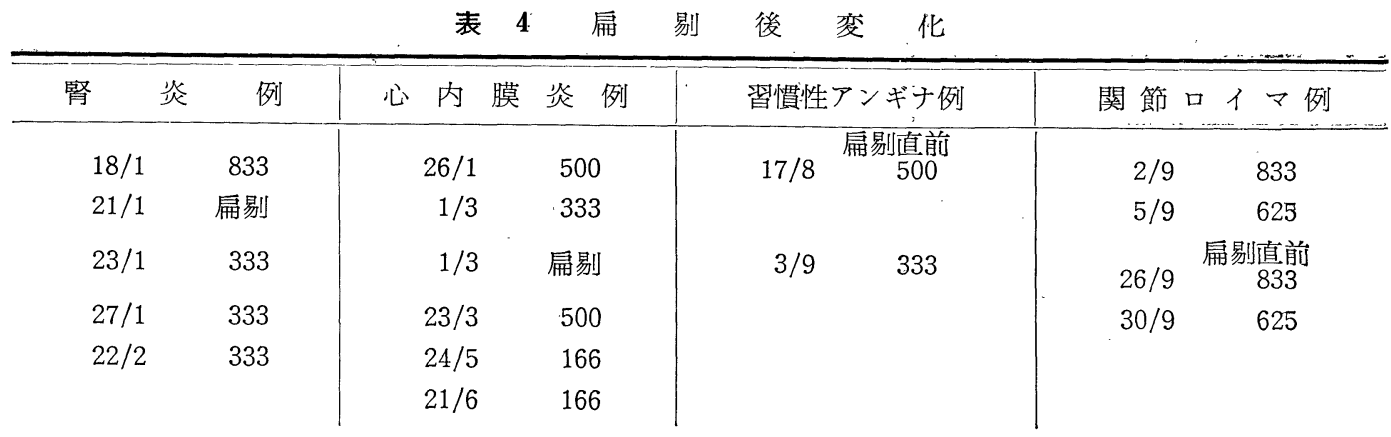

おいてはその中間にあるが如き結果が見られた。さう にまた病巣感染を起せる扁桃を剔出し，その手術の前 後の抗体価を検すると多くは術後においてその低下を 見ている.（表 4 参照）

この検查法は耳鼻科においで漸次范用されてくる ものと思う。しかしてこれによりて扁剔の適示を判定 する方法ともなることと思う。事実数年以上前よりス カンヂナビヤ方面においては，リュウマチスの鑑別に 際し広く用いられ，恰も梅毒に対するワッセルマン反 応の如くに使用されておると云われる。

但しこの単位も地域によつて差異があり，また個人 差もある故に，多くの実験を経て始めて使用に役立つ ものと思われる。

また溶レン菌以外の菌すなわち，ブドー菌の如き場 合には，他の方法を用いて検しなければならない，第 5の診断法として心電図検査がある.

これは病巣感染を起せる場合に心電诚検査を行なう と，しばしば病的所見の得らるることは既に知らるる ところである。これをわが国において最も早く提唱せ るは堂野前教授であつて，氏は慢性属桃资を有するも のにおいては，33.3\%の 数において心電図上に病的所 見すなわち，多くは心筋炎の所見を見たという。しか してかかる扁桃を剔出して再び心電図検查を行なう時 には，明に恢復を見ることの多きを知つた。

その後諸科においてその追試が行なわれ，殊に耳鼻 科方面においてこれを追試してみると，慢性扁桃炎患 者においては，しばしば心電図上において病変が認め られ，これと対照的に行なうた単純なる扁桃腺肥大症 の如き場合には，かかる変化は見られなかつた。

扁桃のみならず，副鼻腔が病巣感染源となれる場合 も同様であつて，しかも成人に限らず小児の場合にお いてもこのことあるを認めた。すなわち，小児副鼻腔 炎の場合にも，その 1 割位の割合において心電図上の
病変を認めたという報告に接していたが，今回東邦医 大名越教授の研究においても，100例の小晶副鼻腔炎 患者および18例の成人例に就て検した結果，表 5 に示 すが如き所見を得た。

すなわち，成人において明かに多い，従来の多くの 研究においても, 慢性副鼻腔炎の患者において相当の 頻度において心電図上において変化を見ている。われ われの処においても嘗て成人の蓄膿症患者においてこ

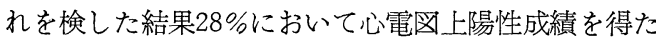
が，名越教授の成績と一致するものがある.

再び扁桃の場合に戻るが，われわれの処において17 例の慢性扁桃炎の患者において，心電図を作成せし に，5例において病変がみられ，しかしてその中の 4 例迄は扁剔後においてその变化は消失した. 鈴木助教 授によれば，この心電図上の変化弾なる反応現象で あつて，臨床上において甚だしき意義を認め妨，過 剩剌㦸が綝返されれば，やがて病理組織的にも認めら るる処の質的変化を来たすものであると云つている。

第 6 の診断法として血漿蛋白分屑法がある．この際 アルブミンの減少とガンマ・グロブリンの増加を認め ることが常であるが，この診断法を過大視してはなら ず，常に他の所見と照し合せて参考に供すべきである とされている。

第 7 の診断法として扁桃の洗滌法がある. 扁姚の腺 䈑よりカニューレを挿入しこれによりて洗滌を試みる のであるが，内部より分泌物の証明さるることがあ る. しかして洗條を数回繰返えし施行することによつ て，従来存していた微熱の下降することがある，ただ し10回以上洗滌を試みても無効の際にはこれを続行す ることは無意味と考えられる。城所博士の報告する処 によれば20例の微熱を有する慢性扁桃炎患者におい て，14例すなわち，70\%において腺窩の洗滌によつて 下熱を見たとのことである， 
表 5 慢性副鼻腔炎患者の EKG 所見

\begin{tabular}{ll|lll|l|l|l|l}
\hline & & & 小少例 & 成人例 & 全 \\
\hline
\end{tabular}

第8 の診断法は扁桃穿刺物の皮内反応である。これ はシュルツおよびライバーによつて始められたもの で，扁桃を穿刺して得た液を皮内に注射して皮膚反応 を検せしところ，被検者の60\%において反応を示せし を見た。すなわち， $8 \mathrm{~mm}$ 程の紅斑を生じ対照例に比す るに明かにその範囲の広きを認めた。またこの際40\% において，血液像の変化殊にエオジノフィリ一を見た という。

第9.の診断法は Imphletol 反応であるが，これは 神紸剤である Imphletol を扁桃の局所に注射すると， 40分以内に関節リューマチスの疼痛が消退するもので あるという。野坂教授は77例にこれを芯用して $65 \%$ の 効果率を挙げ得たを報告されている.

第10は Remky 反応および Weltman 反応であ る. 前者はヒスタミン・テストであるが，これは眼結 膜に打㤆る応を検するものであるが，陽性の場合に は，眼結膜に膨疹を生ずるものである，後者は血清内 蛋白の凝固反応を検するものである.

病巣感染に就ての病理組織学的検查

病理組織学的に病巣感染を起せる扁桃に就ての研究 も従来僅かながらもこれを見ることが出来る。然しい づれもこれをもつて病巣感染に関し決定的の診断は下

\section{結}

し得ない.

病巣感染を起せし扁桃の病理組織的検査に就て見る に，扁桃窩内に死腔を生じ，之の腔内に白血球まだは 組織崩壞物を保有し，腺简の形状は複杂䧴なる形体を呈 し，被膜および隔膜の結合組織が増殖するを認めると いう. 䅗恵医大教室において鈴木弘司氏が 100例.の慢 性扁桃炎の病理組織学的所見を報告しているが，その 内23例の病巣感染を起せるものの所見においては，そ の全部において血管周㘫および血管内膜に変化あるを 認めた。

また慢性嵋桃炎100例の病理所見においては，24\% に静脈リンパ管の慢性血管炎の像を認めたが，内15\% は周囲炎，9\%は管内膜资である。

病巣感染23例の病理所見においては, 左の結果を得 た.

1. 静脈およびリンパ管における血管性細胞浸㵎

2. 静脈およびリシパ管炎

3. 小動脈壁変性

而してこれ等の変化はアレルギーの場合にしぱしば 見らるる血管の変化なるが故に, 病巣感染が二種のア レルギー性変化なることを想はしむものであると報告 している.

\section{び}

病巣感染は耳鼻咽喉科の器官々全身疾患との関連に於て常に興味ある問題を提供しているが，八 
ッキリした診断法のなきままに，従来香角，曖昧模糊の中に包まれている憾みがある。吾々は確実 な診断法の出現を期待している，吾々が扁剔の適応を定める場合に於ても，常に学問的，科学的見

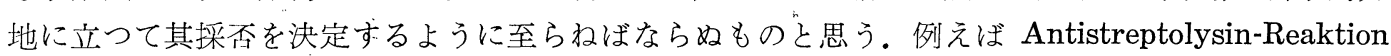
の如き方法が確実性を有するに至れば之等についての端緒が得られるであろう。尚病巣感染は敢て 扁桃のみに限らず副鼻腔蓄膿症に於ても見られる。更に聴器においてもこの問題は関連なしとしな い。この問題の追求は吾耳鼻科に於で最も努めねばならぬものと思方。 